\title{
Enzymatic Synthesis of Surface Active and Biodegradable Glucosaminide Fatty Acid Esters
}

\author{
Tooru SAgOH ${ }^{1}$, Kazunobu Toshima ${ }^{1}$, Kazuo KAWAdA ${ }^{2}$ \\ and Shuichi Matsumura ${ }^{1 *}$ \\ ${ }^{1}$ Department of Applied Chemistry, Faculty of Science and Technology, Keio University \\ (3-14-1, Hiyoshi, Kohoku-ku, Yokohama-shi 223-8522, JAPAN) \\ ${ }^{2}$ School of Science, Kitasato University \\ (1-15-1, Kitasato, Sagamihara-shi 228-8555, JAPAN)
}

Edited by T. Oida, Kyoto Inst. Tec., and accepted June 6, 2003 (received for review March 19, 2003)

\begin{abstract}
Methyl, ethyl and butyl $\beta$-D-glucosaminide 6- $O$-fatty acid esters were prepared by the novel direct transglycosylation reaction of chitosan with methanol, ethanol and butanol using resting cells of the chitosan-assimilating strain, Penicillium sp. KS018 as the enzyme source of exo- $\beta$-D-GlcNase followed by the transesterification reaction with the fatty acid methyl ester using lipase. Transesterification by the lipase depended on enzyme origin, and reaction conditions, such as temperature and reaction pressure. Methyl, ethyl and butyl $\beta$-Dglucosaminide 6-O-fatty acid monoesters demonstrated excellent surface activity in aqueous solution. The antimicrobial properties of the 6-O-dodecanoyl-glucosaminides were stronger compared to dodecyl $\beta$-D-glucoside. The methyl, ethyl and butyl glucosaminide 6 - $O$-fatty acid esters were all readily biodegradable by activated sludge.
\end{abstract}

Key words: enzymatic synthesis, transglycosylation, chitosan, sugar based surfactant, surface activity, glucosaminide fatty acid ester, biodegradation

\section{Introduction}

The greening of chemistry requires the discovery and development of new synthetic pathways using alternative feedstocks, reaction conditions and catalysts for improved selectivity and energy minimization and the designing bio/environmentally compatible chemicals. Some challenges for this include application of biocatalysts and use of naturally abundant and renewable resources, such as polysaccharides and plant oils, as alternative feedstocks.

Chitosan is produced by the deacetylation of chitin which is one of the most abundant biomass forms next to cellulose. D-Glucosamine is a monomeric component of chitosan and has wide application as a hydrophilic moiety of amphiphilic molecules having biological properties and molecular recognition abilities. Such amphiphilic molecules that form supramolecular assemblies involve long chain alkyl glycosides and short or medium chain alkyl glycoside fatty acid esters $(1,2)$. Long chain fattty acid estsers with various sugars, such as glucose, sucrose and raffinose, show excellent surface acitivities and biodegradability (3). Some are used as edible surfactants, such as an emulsifier for food processing. The biodegradation mechanism of sugar esters, such as sucrose esters and the $\alpha$-sulfofatty acid sucrose ester, has also been extensively studied (4).

Though short chain alkyl D-glucosaminides are soluble in water and in organic solvents, the short chain alkyl D-glucosaminides may become versatile interme-

\footnotetext{
*Correspondence to: Shuichi Matsumura, Department of Applied Chemistry, Faculty of Science and Technology, Keio University, 3-14-1, Hiyoshi, Kohoku-ku, Yokohama-shi 223-8522, JAPAN

E-mail: matumura@applc.keio.ac.jp
} 
diates for the production of novel biologically active and environmentally benign amphiphiles. The direct preparation of such glycosides from chitosan and an alcohol using an enzyme may contribute to the establishment of a new field of green chemstry. Glycosides should be produced instead of free sugar units when the hydrolase enzyme has transglycosylation activity and an alcohol is present instead of water in the reaction mixture. The enzymatic preparation of the alkyl glycoside by transglycosylation of polysaccharides, such as xylan (5,6), chitosan (7-9) and cellusose (10), and an alcohol has been reported by us. The short chain alkyl $\beta$-D-glucosaminide 6- $O$-fatty acid ester ( $\mathrm{R}^{\prime}-\mathrm{RGlcN}$ ) was prepared by direct transglycosylation of chitosan and an alcohol using exo- $\beta$-D-glucosaminidase (exo- $\beta$ D-GlcNase) from the chitosan-assimilating strain Penicillium sp. KS 018 with subsequent esterification with fatty acid. Physico-chemical properties as surfactant, and biodegradability and antimicrobial activity were evaluated. The concept of this study and preparation of the surfactant, R'-RGlcN, are shown in Scheme 1.

\section{Experimental}

\subsection{Materials and Measurements}

Methyl octanoate and methyl dodecanoate were purchased from Tokyo Kasei Kogyo Co., Ltd. and distilled under reduced pressure before use. Chitosan was purchased from Katokichi Co., Ltd. (Japan). Porcine pancreatic lipase (41 U/mg protein, according to the supplier) was from Sigma Chemical Co. (St. Louis, MO, USA). Candida antarctica lipase immobilized on acrylic resin [Novozym 435 (triacylglycerol hydrolase + carboxylesterase) having 10,000 PLU/g (propyl laurate units: lipase activity based on ester synthesis)] and Rhizomисor miehei lipase immobilized on a macroporous anion exchange resin (Lipozyme RM IM) were kindly supplied by Novozymes Japan Ltd. (Chiba, Japan). Lipase AK (Pseudomonas fluorescens) was kindly supplied by Amano Pharmaceutical Co., Ltd. (Nagoya, Japan). The enzyme was dried in vacuum over $\mathrm{P}_{2} \mathrm{O}_{5}$ at $25^{\circ} \mathrm{C}$ for $1 \mathrm{~d} .{ }^{1} \mathrm{H}$ and ${ }^{13} \mathrm{C}$ NMR spectra were recorded with a JEOL spectrometer (Tokyo, Japan) at 300 and $75 \mathrm{MHz}$, respectively.

Short chain alkyl $\beta$-D-glucosamides (RGlcN) and their 6-O-fatty acid esters ( $\left.\mathrm{R}^{\prime}-\mathrm{RGlcN}\right)$ were analyzed by a high-performance liquid chromatography (HPLC) with a refractive index detector and a commercial
HPLC column (TSK-GEL NH $\mathrm{N}_{2}-60$, TOSOH, Co., Ltd., Tokyo, Japan, acetonitrile-water as the eluent) calibrated with the chemically synthesized authentic standards.

\section{$2 \cdot 2$ Isolation of Chitosan-Assimilating Microbe and Preparation of Resting Cells as Enzyme Source of Exo- $\beta$-D- GlcNase}

Chitosan-assimilating microbes were isolated from soil using enrichment culture techniques with chitosan as the sole carbon source. The most active fungal strain, KS018, was selected as the chitosan-assimilating strain having transglycosylation activity. The KS018 strain, identified as Penicillium sp. by NCIMB Japan Co., Ltd. (Shimizu-shi, Japan), was grown in an inorganic medium $\left(0.2 \% \mathrm{NH}_{4} \mathrm{Cl}, 0.02 \% \mathrm{~K}_{2} \mathrm{HPO}_{4}, 0.02 \% \mathrm{MgSO}_{4}\right.$. $7 \mathrm{HO}, 0.0002 \% \mathrm{CaCl}_{2}, 0.0001 \% \mathrm{FeSO}_{4} \cdot 7 \mathrm{H}_{2} \mathrm{O}, 0.0002 \%$ $\mathrm{MnSO}_{4} \cdot 4 \mathrm{H}_{2} \mathrm{O}, 0.0007 \% \mathrm{ZnSO}_{4} \cdot 7 \mathrm{H}_{2} \mathrm{O}$, and trace of $\mathrm{CuSO}_{4}$ and Vitamin $\mathrm{B}_{1} \cdot \mathrm{HCl}$ ) containing $0.5 \%$ chitosan as the growing substrate $(200 \mathrm{~mL})$ in a shake flask with reciprocal shaking at $30^{\circ} \mathrm{C}$. Initial $\mathrm{pH}$ of the medium was adjusted to 6.0 with $\mathrm{NaOH}$. At 4-days incubation, the cells were harvested by centrifugation $(9,000 \mathrm{~g}, 15$ $\min , 4^{\circ} \mathrm{C}$ ), washed with saline to obtain $10 \mathrm{~g}$ of wet cells as the enzyme source of exo- $\beta$-D-glucosaminidase (exo- $\beta$-D-GlcNase) for the preparation of alkyl $\beta$-Dglucosaminide (RGlcN). The resting cells showed exo$\beta$-D-GlcNase activity as measured using chitotritol (11).

\section{$2 \cdot 3$ Preparation of RGlcN by Transglycosy- lation of Chitosan and Alcohol Using Resting Cells of Penicillium sp. KS018}

RGlcN was prepared by direct transglycosylation of chitosan and an alcohol using resting cells as biocatalyst as shown in Scheme 1. A typical preparation of methyl $\beta$-D-glucosaminide (MeGlcN) is as follows. A mixture of $50 \mathrm{~mL} 0.5 \%$ aqueous chitosan solution $(\mathrm{pH}$ 4.0), $30 \mathrm{~mL}$ methanol, $10 \mathrm{~g}$ wet cells and $10 \mathrm{~mL}$ acetate buffer $(100 \mathrm{mM}, \mathrm{pH} 6.0)$ was incubated in a shake flask with stirring at $30^{\circ} \mathrm{C}$ for $48 \mathrm{~h}$. Yield of $\mathrm{MeGlcN}$ in the incubation mixture was directly determined by HPLC using an authentic standard. The product was purified by column chromatography and its structure analyzed. After the reaction, the unreacted chitosan was filtered and the filtrate evaporated and purified by column chromatography $\left[\left(\mathrm{SiO}_{2}, \mathrm{CHCl}_{3} / \mathrm{CH}_{3} \mathrm{OH} / 28 \% \mathrm{NH}_{4} \mathrm{OH}=\right.\right.$ $10 / 4 / 1(\mathrm{v} / \mathrm{v}), \mathrm{Rf}=0.2]$ to obtain $\mathrm{MeGlcN}$ in a yield of 


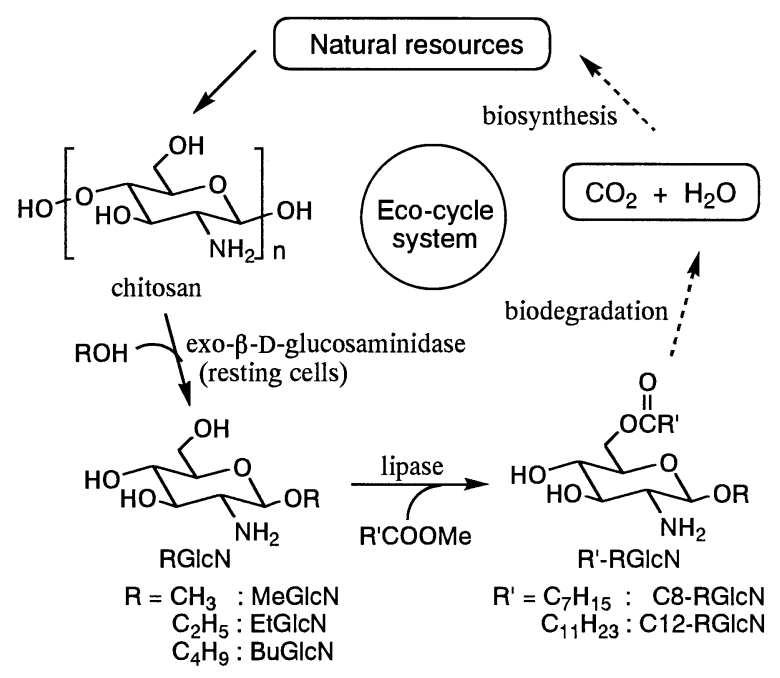

Scheme 1 Preparation of R'-RGlcN and Eco-Cycle System.

$132 \mathrm{mg}$ (527 mg/g chitosan). The isolated product was analyzed by HPLC, elemental analysis, IR, and ${ }^{1} \mathrm{H}$ NMR and ${ }^{13} \mathrm{C}$ NMR spectroscopies. Results for MeGlcN: ${ }^{1} \mathrm{H}$ NMR $\left(270 \mathrm{MHz}: \mathrm{D}_{2} \mathrm{O}\right): \delta=2.50(1 \mathrm{H}, \mathrm{m})$, 3.20-3.35 (3H, m), $3.40(3 \mathrm{H}, \mathrm{s}), 3.59-3.79(1 \mathrm{H}, \mathrm{dd}$, $J=5.6), 3.78-4.02(1 \mathrm{H}, \mathrm{dd}, J=2.2,12.2), 4.20(1 \mathrm{H}, \mathrm{d}$, $J=8.28)$.

Ethyl $\beta$-D-glucosaminide (EtGlcN) and butyl $\beta$-Dglucosaminide $(\mathrm{BuGlcN})$ were prepared by the reaction of chitosan with ethanol and butanol, respectively, using resting cells. EtGlcN: ${ }^{1} \mathrm{H}$ NMR $\left(270 \mathrm{MHz}: \mathrm{D}_{2} \mathrm{O}\right)$ : $\delta=1.15(3 \mathrm{H}, \mathrm{t}, J=7.28), 2.52(1 \mathrm{H}, \mathrm{m}), 3.20-3.35(3 \mathrm{H}$, $\mathrm{m}), 3.40(3 \mathrm{H}, \mathrm{s}), 3.50-3.60(1 \mathrm{H}, \mathrm{dd}, J=2.2,5.6), 3.78$ $(1 \mathrm{H}, \mathrm{dd}, J=2.2,12.2), 4.20(1 \mathrm{H}, \mathrm{d}, J=8.28) . \mathrm{BuGlcN}:{ }^{1} \mathrm{H}$ NMR (270 MHz: $\left.\mathrm{D}_{2} \mathrm{O}\right): \delta=0.93(3 \mathrm{H}, \mathrm{t}, J=8.0), 1.41(2 \mathrm{H}$, $\mathrm{m}), 1.63(2 \mathrm{H}, \mathrm{m}), 2.64(1 \mathrm{H}, \mathrm{dd}, J=9.6), 3.34-3.50(3 \mathrm{H}$, m), 3.63-3.79 (2H, m). 3.90-4.02 (2H, m), $4.39(1 \mathrm{H}, \mathrm{d}$, $J=8.2$ ).

\subsection{Preparation of Methyl, Ethyl and Butyl 6-O-Acyl- $\beta$-D-Glucosaminides ( $R$ '- RGlcN) Using Lipase}

RGlcN and the fatty acid methyl ester were stirred with lipase at constant temperature under a reduced pressure as shown in Scheme 1. Transesterification products were periodically analyzed by HPLC. After the reaction, an aliquot of ethanol was added to the reaction mixture and the insoluble enzyme was removed by suction filtration through a Celite pad. The filtrate was evaporated to obtain the crude product which was purified by column chromatography (silica gel C-300, $\mathrm{CHCl}_{3}-\mathrm{CH}_{3} \mathrm{OH}-28 \% \mathrm{NH}_{4} \mathrm{OH}=20: 5: 1$, v/v). The chemical structure of the isolated product was found by HPLC, elemental analysis, and IR, ${ }^{1} \mathrm{H}$ NMR and ${ }^{13} \mathrm{C}$ NMR spectroscopy. MeGlcN (100 mg), three equivalents methyl dodecanoate $(333 \mathrm{mg}$ ) and $100 \%$ Lipozyme RM IM (100 mg, relative to MeGlcN) were stirred at $70^{\circ} \mathrm{C}$ and 100 Torr for $7 \mathrm{~h}$. After the reaction, $20 \mathrm{~mL}$ ethanol were added and the insoluble enzyme was removed by filtration through a Celite pad. The ethanol was evaporated to obtain the crude product ( 400 $\mathrm{mg}$ ). This was further purified using silica gel column chromatography to obtain methyl 6- $O$-dodecanoyl- $\beta$-Dglucosaminide $(\mathrm{C} 12-\mathrm{MeGlcN})$ in a yield of $63.4 \%$ $(122.3 \mathrm{mg}$ ) as a white powder. A series of R'-RGlcNs were prepared similarly. Results for R'-RGlcN are shown in Table 1.

\subsection{Interfacial Properties}

$2 \cdot 5 \cdot 1$ Static surface tension and occupation area of a molecule at surface $\left(\mathrm{A}_{\min }\right)$

Static surface tension was measured with an automatic digital Kyowa Precise Surface Tensiometer by the CBVP Method (Kyowa Kagaku Co., Ltd., Tokyo, Japan) at $25^{\circ} \mathrm{C}$. Measurement was carried out using the Wilhelmy vertical plate technique and sandblasted glass plate. The test solutions were aged at $25^{\circ} \mathrm{C}$ for at least 1 $\mathrm{h}$ before measurement. Each measurement was made three times and the mean value was taken.

The occupation area of a molecule at a surface $\left(\mathrm{A}_{\min }\right)$ was calculated according to the literature (12). The surface excess concentration $\left(\Gamma_{\max }\right)$ in mole $/ \mathrm{cm}^{2}$, and the corresponding $\mathrm{A}_{\min }$ in $\mathrm{nm}^{2}$, at the liquid/air interface were calculated using equations 1 and 2 :

$\Gamma_{\max }=(1 / 2.303 \mathrm{RT})(\partial \gamma / \partial \log \mathrm{C})_{\mathrm{T}}$

and

$\mathrm{A}_{\min }=10^{14} / \mathrm{N} \Gamma$

where $(\partial \gamma / \partial \log \mathrm{C})_{\mathrm{T}}$ is the slope of the surface tension vs. concentration curves below the $\mathrm{cmc}$ at a constant temperature and $\gamma$ is the surface tension.

$2 \cdot 5 \cdot 2$ Foaming power and emulsification power

Foam properties were measured by the semi-micro TK method at $25^{\circ} \mathrm{C}$ according to Yano and Kimura (13). Initial foam volume in $\mathrm{mL}$ expressed the foam production and foam volume after 5 min expressed foam stability.

Emulsification power was determined by the height of the emulsion layer after shaking a $0.1 \%$ aqueous 
Table 1 Analytical Data for 6- $O$-acylated $\beta$-D-glucosaminides.

\begin{tabular}{|c|c|c|c|c|c|c|c|}
\hline \multirow{3}{*}{ Compound } & \multirow{3}{*}{$\begin{array}{c}{ }^{1} \mathrm{H} \text { NMR } \\
(\delta)\end{array}$} & \multicolumn{6}{|c|}{ Elemental analysis $(\%)$} \\
\hline & & \multicolumn{2}{|c|}{$\mathrm{C}$} & \multicolumn{2}{|c|}{$\mathrm{H}$} & \multicolumn{2}{|c|}{$\mathrm{N}$} \\
\hline & & Found & Calcd. & Found & Calcd. & Found & Calcd. \\
\hline $\mathrm{C} 8 \mathrm{MeGlcN}$ & $\begin{array}{l}0.90(3 \mathrm{H}, \mathrm{t}, J=8.0), 1.20-1.36(8 \mathrm{H}, \mathrm{m}), 1.60(2 \mathrm{H}, \mathrm{m}), 2.40(2 \mathrm{H}, \mathrm{t}, \\
J=7.2), 2.63(1 \mathrm{H}, \mathrm{m}), 3.25-3.40(3 \mathrm{H} . \mathrm{m}), 3.50(3 \mathrm{H}, \mathrm{s}), 4.15(1 \mathrm{H}, \mathrm{d}, \\
J=9.5), 4.25(1 \mathrm{H}, \mathrm{dd}, J=6.3), 4.50(1 \mathrm{H}, \mathrm{dd}, J=2.5,13.2)\end{array}$ & 56.40 & 56.00 & 9.15 & 9.03 & 4.39 & 4.32 \\
\hline C12MeGlcN & $\begin{array}{l}0.88(3 \mathrm{H}, \mathrm{t}, J=8.0), 2.50(1 \mathrm{H}, \mathrm{m}), 1.10-1.50(16 \mathrm{H}, \mathrm{m}), 1.60(2 \mathrm{H}, \mathrm{m}), \\
2.40(2 \mathrm{H}, \mathrm{t}, J=7.7), 2.60(1 \mathrm{H}, \mathrm{m}), 3.20-3.35(3 \mathrm{H}, \mathrm{m}), 3.40(3 \mathrm{H}, \mathrm{s}), \\
4.18(1 \mathrm{H}, \mathrm{d}, J=8.5), 4.25(1 \mathrm{H}, \mathrm{dd}, J=5.6), 4.63(1 \mathrm{H}, \mathrm{dd}, J=2.5,13.2)\end{array}$ & 60.77 & 60.42 & 9.93 & 10.03 & 3.73 & 3.56 \\
\hline C8EtGlcN & $\begin{array}{l}0.85(3 \mathrm{H}, \mathrm{t}, J=8.0), 1.20-1.40(11 \mathrm{H}, \mathrm{m}), 1.65(2 \mathrm{H}, \mathrm{m}), 2.40(2 \mathrm{H}, \mathrm{t}, \\
J=7.8), 2.70(1 \mathrm{H}, \mathrm{m}), 3.28-3.50(3 \mathrm{H}, \mathrm{m}), 3.55(1 \mathrm{H}, \mathrm{s}), 3.95(1 \mathrm{H}, \mathrm{m}), \\
4.20(1 \mathrm{H}, \mathrm{d}, J=8.2), 4.25(1 \mathrm{H}, \mathrm{dd}, J=6.8), 4.60(1 \mathrm{H}, \mathrm{dd}, J=2.3,13.3)\end{array}$ & 57.63 & 57.50 & 9.37 & 9.19 & 4.20 & 4.12 \\
\hline C12EtGlcN & $\begin{array}{l}0.90(3 \mathrm{H}, \mathrm{t}, J=8.2), 1.20-1.45(19 \mathrm{H}, \mathrm{m}), 1.65(2 \mathrm{H}, \mathrm{m}), 2.40(2 \mathrm{H}, \mathrm{t}, \\
J=7.8), 2.70(1 \mathrm{H}, \mathrm{m}), 3.28-3.50(3 \mathrm{H}, \mathrm{m}), 3.60(3 \mathrm{H}, \mathrm{s}), 3.95(1 \mathrm{H}, \mathrm{m}) . \\
4.20(1 \mathrm{H}, \mathrm{d}, J=8.2), 4.25(1 \mathrm{H}, \mathrm{dd}, J=6.6), 4.60(1 \mathrm{H}, \mathrm{dd}, J=2.5,13.1)\end{array}$ & 61.43 & 61.67 & 10.02 & 10.09 & 3.52 & 3.60 \\
\hline C12BuGlcN & $\begin{array}{l}0.90(3 \mathrm{H}, \mathrm{t}, J=8.2), 0.95(3 \mathrm{H}, \mathrm{m}), 1.30-1.50(21 \mathrm{H}, \mathrm{m}), 1.65(2 \mathrm{H}, \mathrm{m}), \\
2.40(2 \mathrm{H}, \mathrm{t}, J=7.8), 2.75(1 \mathrm{H}, \mathrm{m}), 3.25-3.50(3 \mathrm{H}, \mathrm{m}), 3.60(1 \mathrm{H}, \mathrm{m}) \\
3.90(1 \mathrm{H}, \mathrm{m}), 4.20(1 \mathrm{H}, \mathrm{d}, J=8.5), 4.30(1 \mathrm{H}, \mathrm{dd}, J=6.7), 4.55(1 \mathrm{H}, \\
\mathrm{dd}, J=2.5,13.4)\end{array}$ & 63.28 & 62.91 & 10.38 & 10.09 & 3.35 & 3.20 \\
\hline
\end{tabular}

solution $(5 \mathrm{~mL})$ with hexane $(5 \mathrm{~mL})$ for $1 \mathrm{~min}$ at $25^{\circ} \mathrm{C}$. Volumes of emulsion layer, toluene layer and aqueous layer were each measured after a 5-minute stand.

\subsection{Antimicrobial Activity}

The antimicrobial activity of the R'-RGlcN was evaluated by the agar dilution method (14). Gram-positive bacterial strains, Staphylococcus aureus KB210, Bacillus subtilis KB211 and Micrococcus luteus KB212, gram-negative bacterial strains, Escherichia coli KB213, Salmonella typhimurium KB20 and Pseudomonas aeruginosa KB115 and five fungal strains, Candida albicans KF1, Saccharomyces cerevisiae KF25, Trichophyton mentagrophytes KF213, Penicillium chrysogenum KF270 and Aspergillus niger KF103 were used. Nutrient agar and Sabouraud dextrose agar were used for bacterial and fungi, respectively. Antimicrobial activity was expressed as minimum inhibitory concentration (MIC).

\section{$\mathbf{2} \cdot \mathbf{7} \quad$ Hydrolytic Stability}

A hydrolytic stability test was carried out by dissolv- ing R'-RGlcN in buffer solution at $\mathrm{pH} 4,7,8$ and 10. The monoester at $1000 \mathrm{mg} / \mathrm{L}$ was incubated at $30^{\circ} \mathrm{C}$ in an incubator. Solutions of $0.1 \mathrm{M}$ acetate buffer at $\mathrm{pH}$ 4.0, 0.07 $\mathrm{M}$ phosphate buffer at $\mathrm{pH} 7.0$, and $0.05 \mathrm{M}$ glycine- $\mathrm{NaOH}$ buffer at $\mathrm{pH} 8.0$ and 10.0 were used for the nonenzymatic degradation test. Degradation of the monoester was analyzed by HPLC, and hydrolytic stability expressed as remaining \% ester.

\section{$2 \cdot 8$ Biodegradation}

R'-RGlcN biodegradability was evaluated by biochemical oxygen demand (BOD). BOD was determined with a BOD Tester (Model 200F; TAITEC Corp., Koshigaya-shi) using the oxygen consumption method, according to the Modified MITI Test (15). Activated sludge was obtained from a municipal sewage plant in Yokohama City. 


\section{Results and Discussion}

\subsection{Preparation of RGlcN by Transglycosy- lation of Chitosan and Alcohol Using Resting Cells}

Resting cells of Penicillium sp. KS018 were capable of transglycosylation and $\mathrm{MeGlcN}$ was produced by the direct reaction of chitosan and methanol with a yield of $530 \mathrm{mg} / \mathrm{g}$ chitosan. No MeGlcN was produced using monomeric D-glucosamine or N-acetyl-D-glucosamine in place of chitosan. Transglycosylation between chitosan and methanol using resting cells of Penicillium sp. KS018 was analyzed with respect to the reaction conditions. Yield of RGlcN gradually increased with incubation time, and after a 2-day incubation, reached constant value. The yield increased with temperature up to $30^{\circ} \mathrm{C}$ and then decreased probably due to deactivation of the enzyme. Reaction temperature, giving the highest yield of RGlcN, was $30^{\circ} \mathrm{C}$. The yield quickly increased to maximum value with alcohol concentration from 0.2 to $10 \%$ and then slightly decreased due to deactivation of the enzyme by high alcohol concentration. Figure 1 shows yields of RGlcN using methanol, ethanol and butanol during a 2-day incubation at $30^{\circ} \mathrm{C}$. Yield decreased with chain length of the alcohol.

\section{$3 \cdot 2$ Enzymatic Synthesis of Methyl, Ethyl and Butyl 6-O-Acyl- $\beta$-D-Glucosamin- ides}

Methyl, ethyl and butyl $\beta$-D-glucosaminides $(\mathrm{RGlcN})$ were reacted with methyl dodecanoate and octanoate by lipase to produce the corresponding $6-O$ -

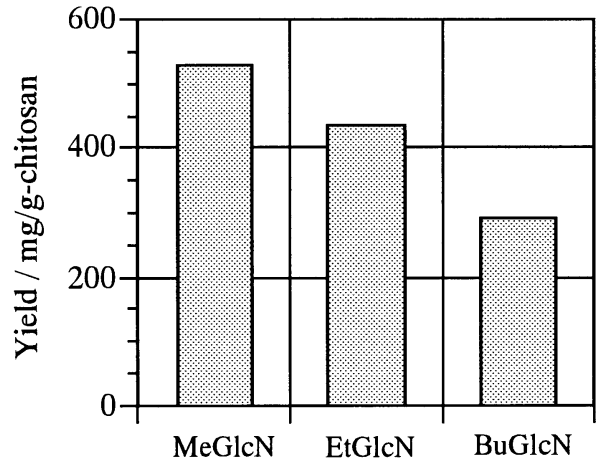

Fig. 1 Preparation of RGlcN by Transglycosylation of Chitosan with Methanol, Ethanol and Butanol Using Resting Cells of Penicillium sp. KS 018 at $30^{\circ} \mathrm{C}$ for 2 Days.

acylated $\beta$-D-glucosaminides ( $\mathrm{R}^{\prime}$-RGlcN). Esterification was significantly influenced by enzyme origin, reaction temperature, molar ratio of the two reactants, reaction time, enzyme concentration, reaction pressure and organic solvent.

\section{$3 \cdot 2 \cdot 1 \quad$ Effects of enzyme origin}

Lipases from various origins were screened for 6-Omonoesterification of RGlcN and methyl dodecanoate at $70^{\circ} \mathrm{C}$. Table 2 shows $6-O$-esterification results for MeGlcN with methyl dodecanoate. Lipozyme RM IM showed the best results for the 6-O-monoester synthesis. Without lipase, no significant 6-O-esterification occurred suggesting the lipase (Lipozyme RM IM) to actually catalyzed esterification.

$3 \cdot 2 \cdot 2$ Effects of reaction temperature

The reaction temperature significantly influenced

Table 2 Effects of Enzyme Origin on Yield of Methyl 6-O-dodecanoyl- $\beta$ D-glucosaminide $(\mathrm{C} 12-\mathrm{MeGlcN})^{\mathrm{a})}$.

\begin{tabular}{clccccc}
\hline Entry & \multicolumn{1}{c}{ Lipase } & $\begin{array}{c}\text { Molar ratio of } \\
\text { MeDo/MeGlcN }\end{array}$ & Solvent & $\begin{array}{c}\text { Pressure } \\
(\text { Torr })\end{array}$ & $\begin{array}{c}\text { Time } \\
(\mathrm{h})\end{array}$ & $\begin{array}{c}\text { Yield } \\
(\%)\end{array}$ \\
\hline 1 & Lipozyme RM IM & $5 / 1$ & - & 80 & 5 & 73 \\
2 & Novozym 435 & $5 / 1$ & - & 80 & 5 & 63 \\
3 & lipase AK & $5 / 1$ & - & 80 & 5 & 15 \\
4 & PPL & $5 / 1$ & - & 80 & 5 & 10 \\
5 & Lipozyme RM IM & $1 / 1$ & - & 80 & 5 & 30 \\
6 & Lipozyme RM IM & $1 / 1$ & THF & 760 & 2 & 0 \\
7 & Novozym 435 & $1 / 1$ & THF & 760 & 24 & 52 \\
8 & lipase AK & $1 / 1$ & THF & 760 & 24 & 0
\end{tabular}

a) Esterification carried out in bulk using methyl dodecanoate (MeDo) and $\mathrm{MeGlcN}$ with $100 \%$ lipase (relative to $\mathrm{MeGlcN}$ ) at $70{ }^{\circ} \mathrm{C}$ 


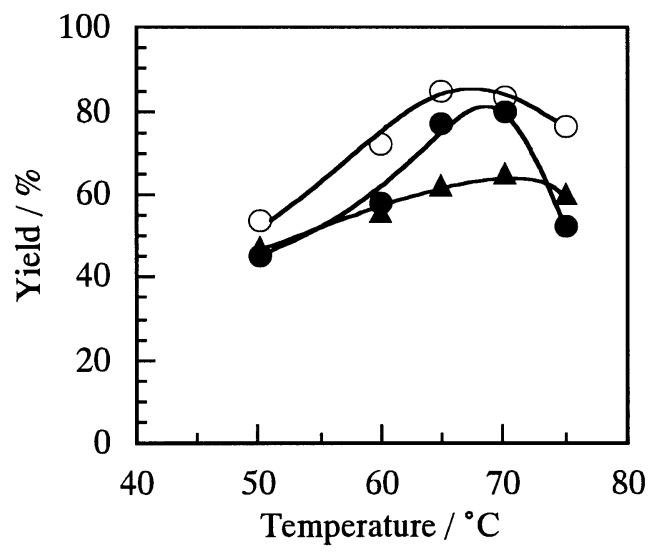

Fig. 2 Effects of Temperature on Yield of R'-RGlcN. MeGlcN and methyl dodecanoate reacted with $100 \%$ Lipozyme RM IM at 80 Torr for 7 h. $\bigcirc:$ C12MeGlcN, O: C8-MeGlcN, $\mathbf{A}:$ C12EtGlcN.

yield of the 6-O-monoester (R'-RGlcN). Figure 2 shows the relationship between yield and temperature for $\mathrm{Me}$, Et and BuGlcN with methyl dodecanoate and octanoate. The highest yield was obtained by the esterification around $70^{\circ} \mathrm{C}$. 6-O-Monoester yield decreased with temperature higher than $70^{\circ} \mathrm{C}$ probably due to deactivation of the enzyme.

$3 \cdot 2 \cdot 3$ Effects of substrate molar ratio

The molar ratio of fatty acid methyl ester and RGlcN was responsible for 6-O-monoester yield due to equilibrium shift of the reaction system. Figure 3 shows the

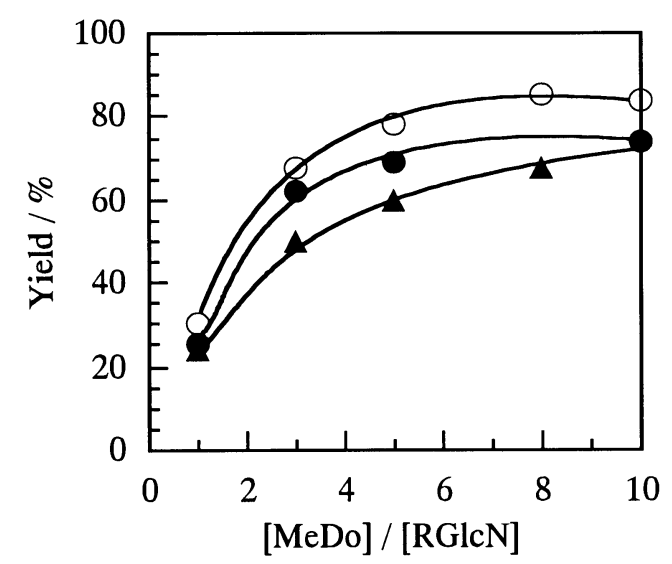

Fig. 3 Effects of Molar Ratio of Methyl Dodecanoate (MeDo) and RGlcN on Yield of C12-RGlcN.

RGlcN and methyl dodecanoate reacted with $100 \%$ Lipozyme RM IM at $70^{\circ} \mathrm{C}$ and 80 Torr for $7 \mathrm{~h}$. $\bigcirc$ : C12-MeGlcN, O: C12-EtGlcN, $\mathbf{\Delta}$ : C12-BuGlcN. relationship between yield and molar ratio of the two reactants. The same was observed such that 6-Omonoester yield increased with methyl dodecanoate ratio. At least 3 equivalents methyl dodecanoate versus RGlcN were necessary to obtain a $60 \% 6-O$-monoester yield.

\section{$3 \cdot 2 \cdot 4$ Time course of esterification}

Figure 4 shows the time course of the transesterification of RGlcN and methyl dodecanoate by Lipozyme RM IM at a molar ratio of 5. A mixture of methyl dodecanoate $(214 \mathrm{mg}, 10 \mathrm{mmol}), \mathrm{RGlcN}(2 \mathrm{mmol})$ and Lipozyme RM IM ( $100 \%$ relative to $\mathrm{RGlcN})$ was stirred at $70^{\circ} \mathrm{C}$ and 80 Torr. Aliquots of the reaction mixture were periodically withdrawn and directly analyzed by HPLC. Yield of the 6-O-monoester gradually increased to an equilibrium value after $6 \mathrm{~h}$. The yield of monoester was then almost constant.

\section{$3 \cdot 2 \cdot 5$ Effects of enzyme concentration}

Enzyme concentration was responsible for the rate of the reaction as shown in Fig. 5. At least 100\% immobilized lipase was necessary for efficient esterification. More enzyme caused no increase in ester yield. The present experiment requires a relatively large amount of enzyme. However, the enzyme could be repeatedly used without significant decrease in activity. In order to establish a practical method for esterification, a continuous bioreactor using the immobilized enzyme is now under study.

\section{$3 \cdot 2 \cdot 6$ Effects of the solvent}

Organic solvent may facilitate transesterification by

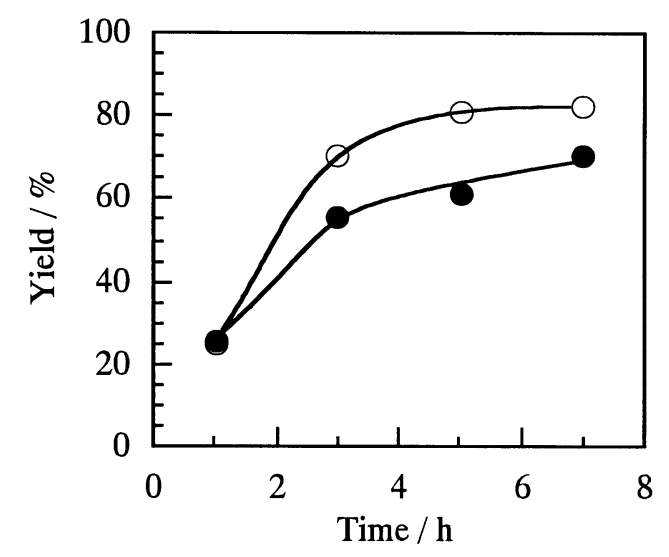

Fig. 4 Time Course of C12-RGlcN Yield.

RGlcN and methyl dodecanoate at molar ratio of $1 / 5$ reacted with $100 \%$ Lipozyme $\mathrm{RM}$ IM at $70^{\circ} \mathrm{C}$ and 80 Torr. $\bigcirc$ : C12-MeGlcN, : C12EtGlcN. 


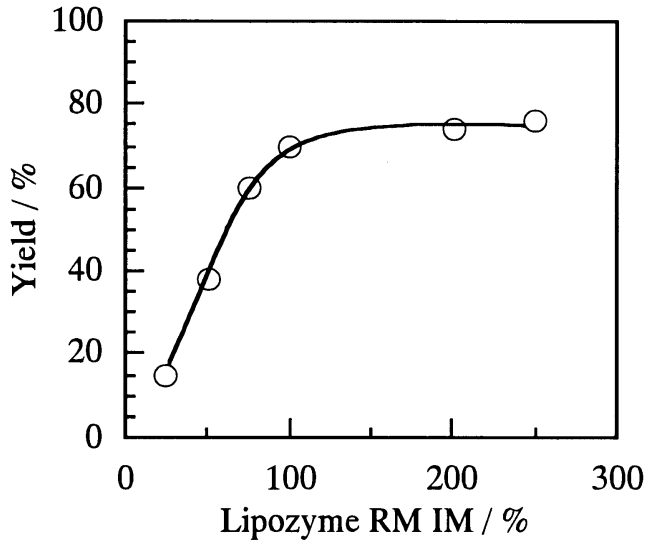

Fig. 5 Effects of Enzyme Concentration on Yield of C12MeGlcN.

MeGlcN and methyl dodecanoate $(1 / 5, \mathrm{~mol} / \mathrm{mol})$ were reacted with $100 \%$ Lipozyme RM IM (relative to $\mathrm{MeGlcN}$ ) at $70^{\circ} \mathrm{C}$ and 80 Torr for $5 \mathrm{~h}$.

diffusion of the two substrates. Therefore, an equimolar mixture of the two substrates was used for the reaction instead of excess fatty acid esters when using an organic solvent. Lipases from various origins were compared with respect to monoester synthesis in tetrahydrofuran (THF) at $70^{\circ} \mathrm{C}$. Only Novozym 435 exhibited activity for monoester synthesis in THF. However, no esterification occurred using Lipozyme RM IM which showed excellent activity under bulk conditions, possibly due to deactivation of the enzyme by organic solvent. The effects of the organic solvent on monoester yields were compared for various solvents, such as THF, acetonitrile, dimethyl formamide, toluene and tert-butanol, at $70^{\circ} \mathrm{C}$ for a $24-\mathrm{h}$ reaction. The results are summarized in

Table 2. The best results were obtained when THF was used as the solvent. It was confirmed that 6 - $O$-dodecanoyl MeGlcN (C12-MeGlcN) was obtained in 54\% yield by reaction of an equal molar methyl dodecanoate and MeGlcN in THF at $70^{\circ} \mathrm{C}$ for $24 \mathrm{~h}$. Without solvent, excess methyl ester as solvent was essential for esterification.

$3 \cdot 2 \cdot 7 \quad$ Effects of reaction pressure

Reaction pressure influences esterification by equilibrium shift of the reaction system. Figure 6 shows the effects of the reaction pressure on reaction of RGlcN and methyl dodecanoate at $70^{\circ} \mathrm{C}$ between 760 and 40 Torr. The highest yield was obtained when RGlcN and methyl dodecanoate reacted at 100 Torr.

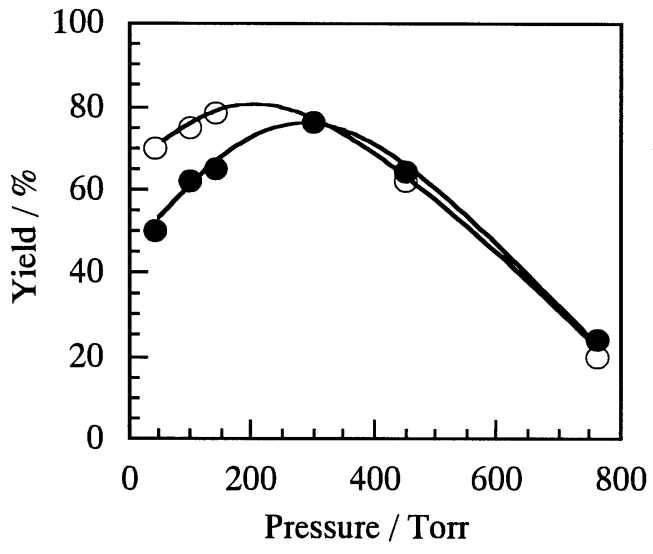

Fig. 6 Effects of Reaction Pressure on Yield of C12MeGlcN.

MeGlcN and methyl dodecanoate $(1 / 5, \mathrm{~mol} / \mathrm{mol})$ reacted with $100 \%$ Lipozyme RM IM (relative to $\mathrm{MeGlcN}$ ) at $70^{\circ} \mathrm{C}$ for $5 \mathrm{~h}$. $\bigcirc$ : C12-MeGlcN, C12-EtGlcN.

\section{$3 \cdot 3$ Interfacial Properties of R'-RGlcN in Aqueous Solution}

RGlcN octanoic and dodecanoic acid 6- $O$ monoesters (R'-RGlcN) exhibited surface activity, such as surface tension depression, micelle formation and foaming properties. From surface tension versus concentration plots for fatty acid 6-O-monoesters in distilled water, critical micelle concentration $(\mathrm{cmc})$ determined from inflection of surface tension versus concentration curve, surface tension at $\mathrm{cmc}\left(\gamma_{\mathrm{cmc}}\right)$, efficiency of adsorption at the surface $\left(\mathrm{pC}_{20}\right)\left[\mathrm{pC}_{20}\right.$, negative $\log$ of $\mathrm{C}_{20}$ the surfactant molar concentration required to reduce surface tension by $20 \mathrm{mN} / \mathrm{m}](16,17)$, and $\mathrm{A}_{\text {min }}$ of fatty acid 6-O-monoesters are summarized in Table 3 along with reference data for n-dodecyl poly(oxyethylene) ether $(\mathrm{n}=6)\left(\mathrm{C}_{12} \mathrm{EO}_{6}\right)$ measured under the same conditions. Cmc was dependent on length of the acyl chain length and the aglycones of RGlcN. The shorter the acyl chain, the higher was cmc. $\gamma_{\mathrm{cmc}}$ of RGlcN fatty acid 6-O-monoesters were lower compared to $\mathrm{C}_{12} \mathrm{EO}_{23}$.

Foaming properties were examined by the semimicro TK method at $\mathrm{cmc}$ at $25^{\circ} \mathrm{C}$ and are summarized in Fig. 7. Excellent foam production and stability were observed for C12-EtGlcN. C12-BuGlcN showed high foam production but low stability similar to the polyethylene glycol monoalkyl ether, such as $\mathrm{C}_{12} \mathrm{EO}_{6}$ and n-dodecyl poly(oxyethylene) ether $(n=25)$ $\left(\mathrm{C}_{12} \mathrm{EO}_{25}\right)$. 
Table 3 Surface Activity of 6-O-acylated Glucosaminides at $25^{\circ} \mathrm{C}$.

\begin{tabular}{lcccc}
\hline Compound & $\begin{array}{c}\mathrm{cmc} \\
(\mathrm{mmol} / \mathrm{L})\end{array}$ & $\begin{array}{c}\gamma_{\mathrm{cmc}} \\
(\mathrm{mN} / \mathrm{m})\end{array}$ & $\mathrm{pC}_{20}$ & $\begin{array}{c}\mathrm{A}_{\min } \times 10^{2} \\
\left(\mathrm{~nm}^{2}\right)\end{array}$ \\
\hline $\mathrm{C} 8-\mathrm{MeGlcN}$ & 8.58 & 28.2 & 3.2 & 43.8 \\
$\mathrm{C} 8-\mathrm{EtGlcN}$ & 5.39 & 29.5 & 3.4 & 49.8 \\
$\mathrm{C} 8-\mathrm{BuGlcN}$ & 2.76 & 26.0 & 3.9 & 48.7 \\
$\mathrm{C} 12-\mathrm{MeGlcN}$ & 1.68 & 26.8 & 3.7 & 24.9 \\
$\mathrm{C} 12-\mathrm{EtGlcN}$ & 0.473 & 28.0 & 4.7 & 37.1 \\
$\mathrm{C} 12-\mathrm{BuGlcN}$ & 0.0719 & 27.6 & 5.7 & 55.9 \\
$\mathrm{C}_{12} \mathrm{EO}_{6}$ & 0.110 & 31.3 & 5.5 & 66.7 \\
\hline
\end{tabular}

Emulsification power was determined by shaking $0.1 \%$ aqueous sample solution $(5 \mathrm{~mL})$ and hexane $(5$ $\mathrm{mL}$ ) for $1 \mathrm{~min}$ at $25^{\circ} \mathrm{C}$. Volumes of the emulsion, toluene and aqueous layers after a 5-minute stand are shown in Fig. 8. The dodecyl ester showed excellent emulsification power compared to conventional polyoxyethylene dodecyl ether type nonionics. C12-BuGlcN showed the strongest emulsification power for the hexane-water system.

\subsection{Hydrolytic Degradation}

The characteristic feature of the ester-type surfactant may be the hydrolytic degradability, possibly responsible for quick biodegradation. A hydrolytic degradation test was carried out by dissolving the esters in buffer solutions at $\mathrm{pH} 4,7,8$ and 10 . The results are shown in Fig. 9. R'-RGlcNs were quite stable at pHs 4 and 7 but

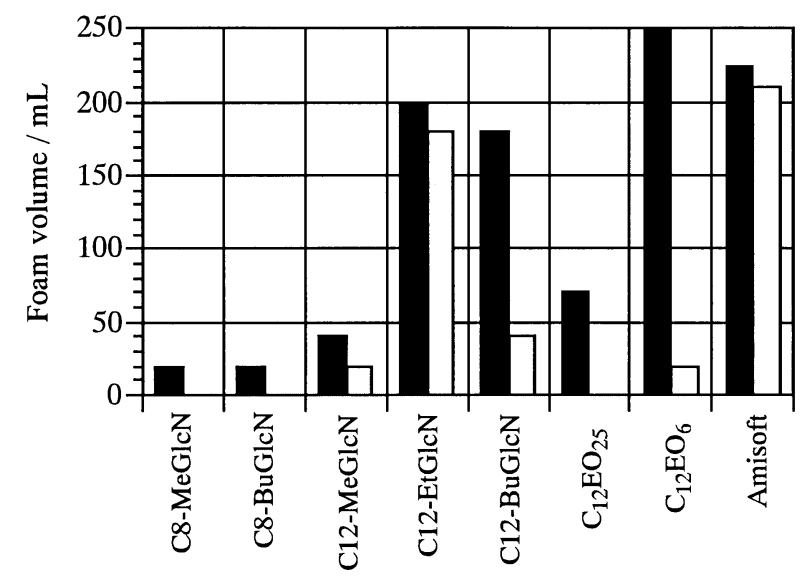

Fig. 7 Foam Production and Stability by Semi-Micro TK Method at $1.0 \%$ Sample Concentration and $25^{\circ} \mathrm{C}$. Black : 0 min, white: 5 min. gradually hydrolyzed at $\mathrm{pH} 8$ and quickly so at $\mathrm{pH} 10$ at $30^{\circ} \mathrm{C}$.

\subsection{Biodegradation}

A quick and complete biodegradation after use is one of the indispensable factors for the next generation surfactants, because water-soluble surfactants are generally difficult to recover or recycle. The biodegradation of R'-RGlcN occurs by hydrolytic cleavage of ester bonds to liberate fatty acid and the corresponding RGlcN. A convenient way to predict aerobic biodegradability is to measure BOD. The biodegradability of R'-RGlcN was evaluated based on BOD. BOD was measured with a BOD tester, using activated sludge at substrate concentration of $15 \mathrm{mg} / \mathrm{L}$. Figure 10 shows the time course of the biodegradation $(\mathrm{BOD} / \mathrm{ThOD} \times 100)$ of R'-RGlcN based on BOD and theoretical oxygen demand (ThOD). All samples were equally biodegraded at more than $60 \%$ after $10 \mathrm{~d}$, which can be considered as readily biodegradable. On the other hand, the biodegradation rate of a conventional ethoxylated alcohol, such as $\mathrm{C}_{12} \mathrm{EO}_{6}$, was less than that of R'-RGlcN under the same conditions.

\subsection{Antimicrobial Activity}

R'-RGlcNs were screened for antimicrobial activity toward gram-positive and gram-negative bacterial and

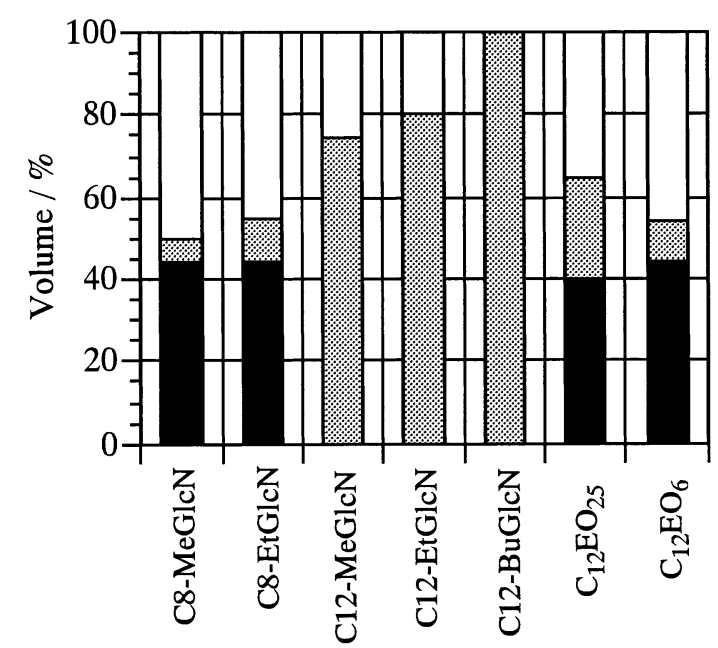

Fig. 8 Emulsion of $0.1 \%$ Aqueous Solution $(5 \mathrm{~mL})$ and Benzene $(5 \mathrm{~mL})$ by Shaking for $1 \mathrm{~min}$ at $25^{\circ} \mathrm{C}$. Volumes of emulsification (grey), hexane (white) and aqueous layers (black) were measured after 5minute stand. 


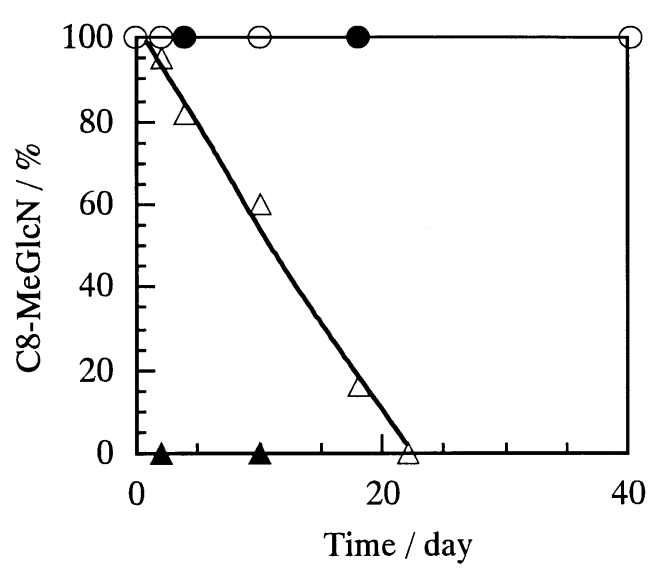

Fig. 9 Hydrolysis of $\mathrm{C} 8-\mathrm{MeGlcN}$ in Aqueous Solution (3000 ppm) of Different $\mathrm{pHs}$ at $30^{\circ} \mathrm{C}$.

$\bigcirc: \mathrm{pH} 4.0, \bigcirc \mathrm{pH} 7.0, \triangle: \mathrm{pH}$ 8.0, $\mathbf{\Delta}: \mathrm{pH} 10.0$.

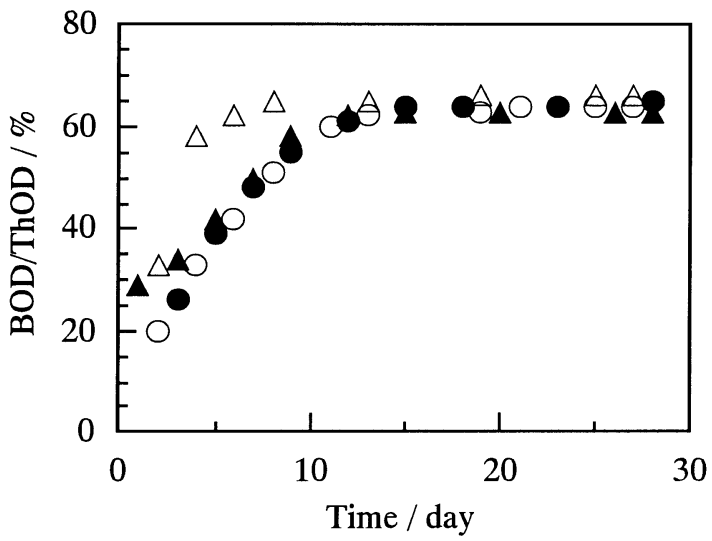

Fig. 10 BOD Biodegradability of R'-RGlcN at $30^{\circ} \mathrm{C}$. Activated sludge: $30 \mathrm{ppm}$, sample: $15 \mathrm{ppm}$. O: C12-MeGlcN, O: C12-EtGlcN, $\triangle:$ C8EtGlcN, $\mathbf{\Delta}:$ C8-BuGlcN.

Table 4 Antimicrobial Activity of 6- $O$-acylated $\beta$-D-glucosaminides.

\begin{tabular}{|c|c|c|c|c|c|c|}
\hline \multirow{2}{*}{$\begin{array}{c}\text { Compounds/ } \\
\text { organism }\end{array}$} & \multicolumn{6}{|c|}{ MIC $(\mathrm{mg} / \mathrm{mL})$} \\
\hline & C8-MeGlcN & C12-MeGlcN & C8-EtGlcN & C12-EtGlcN & $\mathrm{C}_{12} \mathrm{EO}_{6}$ & $\mathrm{C}_{12} \beta \mathrm{Glc}^{\mathrm{a}}$ \\
\hline S. aureus & $>400$ & 50 & 400 & 20 & 50 & 25 \\
\hline B. subtilis & $>400$ & 25 & 400 & 10 & 50 & 50 \\
\hline M. luteus & $>400$ & 10 & 400 & 10 & 50 & - \\
\hline E. coli & $>400$ & 25 & 200 & 25 & $>400$ & $>400$ \\
\hline S. typhimurium & $>400$ & 25 & 400 & 25 & $>400$ & $>400$ \\
\hline P. aeruginosa & $>400$ & $>400$ & 400 & $>400$ & $>400$ & $>400$ \\
\hline C. albicans & $>400$ & 200 & 400 & 100 & $>400$ & 50 \\
\hline S. cerevisiae & $>400$ & 200 & 200 & 100 & 200 & 25 \\
\hline T. mentagrophytes & $>400$ & 10 & 100 & 10 & 50 & - \\
\hline P. chrysogenum & $>400$ & 400 & $>400$ & 400 & 100 & 200 \\
\hline A. niger & $>400$ & $>400$ & $>400$ & $>400$ & 100 & 200 \\
\hline
\end{tabular}

${ }^{\text {a }} \mathrm{C}_{12} \beta$ Glc: Dodecyl $\beta$-D-glucopyranoside (18)

fungal strains. Minimum inhibitory concentrations (MIC) are given in Table 4. C12-RGlcN with a dodecanoyl group showed a broad spectrum of antimicrobial activity. Antimicrobial activity of C12-RGlcNs was greater than that of 1 -dodecyl $\beta$-D-glucopyranoside $\left(\mathrm{C}_{12} \beta \mathrm{Glc}\right)$ (18) or conventional n-dodecyl tetra(oxyethylene) ether $\left(\mathrm{C}_{12} \mathrm{EO}_{4}\right)(18)$ toward Escherichia coli and Salmonella typhimurium.

\section{Conclusions}

Methyl, ethyl and butyl $\beta$-D-glucosaminide 6- $O$-fatty acid esters were prepared by the novel direct transglycosylation reaction of chitosan with methanol, ethanol and butanol using resting cells of the chitosan-assimilating strain, Penicillium sp. KS018 followed by the transesterification reaction with the fatty acid methyl ester using Lipozyme RM IM under reduced pressure. The methyl, ethyl and butyl 6- $O$-acyl- $\beta$-D-glucosaminides exhibited excellent surface activity and 
biodegradability.

\section{Acknowledgments}

Immobilized lipases from Candida antarctica (Novozym 435) and from Rhizomucor miehei (Lipozyme RM IM) were supplied by Novozymes Japan Ltd. (Chiba, Japan). This work was partially supported by a Grant-in-Aid for the 21st Century COE Program "KEIO LCC" from the Ministry of Education, Culture, Sports, Science, and Technology, Japan.

\section{References}

1. K. ADELHORST, F. BIORKLING, S.E. GODTFREDSEN and O. KIRK, Enzyme Catalyzed Preparation of 6-O-Acylglucopyranosides, Synthesis, 112-115 (1990).

2. R.T. OTTO, U.T. BORNSCHEUER, C. SYLDATK and R.D. SCHMID, Synthesis of Aromatic n-Alkyl-Glucoside Esters in a Coupled $\beta$-Glucosidase and Lipase Reaction, Biotechnol. Lett., Vol. 20, 437-440 (1998).

3. I.J.A. BAKER, R.B. MATTHEWS, H. SUARES, I. KRODKIEWSKA, D.N. FURLONG, F. GRIESER and C.J. DRUMMOND, Sugar Fatty Acid Ester Surfactants: Structure and Ultimate Aerobic Biodegradability, J. Surf. Deterg., Vol. 3, 1-11 (2000).

4. I.J.A. BAKER, R.I. WILLING, D.N. FURLONG, F. GRIESER and C.J. DRUMMOND, Sugar Fatty Acid Ester Surfactants: Biodegradation Pathways, J. Surf. Deterg., Vol. 3, 13-27 (2000).

5. S. MATSUMURA, K. SAKIYAMA and K. TOSHIMA, Prepartion of Octyl $\beta$-D-Xylobioside and Xyloside by Xylanase-Catalyzed Direct Transglycosylation Reaction of Xylan and Octanol, Biotech. Lett., Vol. 21, 17-22 (1999).

6. S. MATSUMURA, K. SAKIYAMA and K. TOSHIMA, One-Pot Synthesis of Alkyl $\beta$-D-Xylobioside from Xylan and Alcohol by Acetone Powder of Aureobasidium pullulans, Biotech. Lett., Vol. 19, 1249-1253 (1997).

7. S. MATSUMURA, T. NAKAMURA, E. YAO and T. TOSHIMA, Biocatalytic One-Step synthesis of n-Octyl $\beta$-D-Xylotrioside and Xylobioside from Xylan and n-Octanol in Supercritical Carbon Dioxide, Chem. Lett., 581-582 (1999).
8. S. MATSUMURA, E. YAO and K. TOSHIMA, One-Pot Preparation of Alkyl $\beta$-D-Glucosaminide by the Transglycosylation of Chitosan and Alcohol Using Purified exo- $\beta$-D-glucosaminidase, Biotech. Lett., Vol. 21, 451-456 (1999).

9. S. MATSUMURA, E. YAO, K. SAKIYAMA and K. TOSHIMA, Novel Direct Preparation of n-Butyl 2-Amino-2-deoxy- $\beta$-D-Glucopyranoside from Chitosan and n-Butanol Using Biocatalyst, Chem. Lett., 373-374 (1999).

10. S. MATSUMURA, H. TSURUTA and K. TOSHIMA, One-Pot Synthesis of 1-Octyl $\beta$-D-Glucoside from Cellulose and 1Octanol in Combination of Cellulase and $\beta$-Glucosidase, J. Jpn Oil Chem. Soc., Vol. 48, 15-19 (1999).

11. F. NANJO, R. KATSUMI and K. SAKAI, Purification and Characterization of an Exo- $\beta$-D-glucosaminidase, a Novel Type of Enzyme, from Nocardia orientalis, J. Biol. Chem., Vol. 265, 10088-10094 (1990).

12. C.-C. KWAN and M.J. ROSEN, Relationship of Structure to Properties in Surfactants. 9. Syntheses and Properties of 1,2- and 1,3-Alkanediols, J. Phys. Chem., Vol. 84, 547-551 (1980).

13. W. YANO and W. KIMURA, Studies on the Evaluation Methods of Surface Active Agents. II. Foam Test: Semimicro Improved TK-Method, Yukagaku, Vol. 11, 138-144 (1962).

14. R.G. BRISTLINE, JR., E.W. MAURER, F.D. SMITH and W.M. LINFIELD, Fatty Acid Amides and Anilides, Syntheses and Antimicrobial Properties, J. Am. Oil Chem. Soc., Vol. 57, 98-103 (1980).

15. OECD Guidelines for Testing of Chemicals, 301C, Modified MITI Test, Organization for Economic Cooperation and Development (OECD), Paris, 1981.

16. Y.-P. ZHU, A. MASUYAMA, Y. NAKATSUJI and M. OKAHARA, Synthesis and Properties of Bis(sulfonate) Types of Double-Chain Surfactants Bearing a Sulfur Atom in the Connecting Part, Yukagaku, Vol. 42, 86-94 (1993).

17. Y.-P. ZHU, K. ISHIHARA, A. MASUYAMA, Y. NAKATSUJI and M. OKAHARA, Preparation and Properties of DoubleChain Bis(quaternary ammonium) Compounds, Yukagaku, Vol. 42, 161-167 (1993).

18. S. MATSUMURA, K. IMAI, S. YOSHIKAWA, K. KAWADA and T. UCHIBOIRI, Surface Activities, Biodegradability and Antimicrobial Properties of n-Alkyl Glucosides, Mannosides and Galactosides, J. Am. Oil Chem. Soc., Vol. 67, 996-1001 (1990). 